\title{
INDIRECT APPROACH TO ACCOUNTABILITY OF CORPORATE ENTITIES THROUGH THE LENS OF THE CASE-LAW OF THE EUROPEAN COURT OF HUMAN RIGHTS
}

\author{
Abstract
}

The case law of the European Court of Human Rights (ECtHR) pertaining to human rights protection of legal persons, including corporate entities, is well developed and extensively analyzed in legal literature. The international law of human rights is in the process of transformation from imposition of obligations only on States, to gradually taking into consideration the accountability of non-State actors, particularly corporate entities. The objective of the paper is to analyze the conceptualization of corporate accountability for violations of human rights in the case law of the ECtHR. The paper shows that the ECtHR thus far has approached the corporate accountability and has called for regulation of corporate activities at the national level by means of applying the doctrine of horizontal effect of rights guaranteed by the European Convention on Human Rights (ECHR) referred to as Drittwirkung and the doctrine of positive obligations of the states. The authors argue that the ECtHR so far in its jurisprudence has missed to fully take into account the overarching social and policy developments, and that it should take a more proactive role in conceptualizing its approach to violations of human rights committed by corporate entities.

Keywords: corporate accountability, human rights, ECtHR, violation of human rights, horizontal effect, positive obligations of states.

\section{Introduction}

The international law of human rights is in the process of transformation from imposition of obligations only on States - to gradually taking into consideration the accountability of non-State actors particularly corporations. The concept of corporate accountability gained

\footnotetext{
* Research Fellow, Institute of Comparative Law, Belgrade, e-mail: v.coric@iup.rs.

${ }^{* *}$ Research Fellow, Institute of Comparative Law, Belgrade, e-mail: a.bojovic@iup.rs.
} 
more and more importance over time. It has been even described as "the human rights issue of the 21 st century". ${ }^{1}$

The United Nations (UN) Human Rights Council's Protect, Respect and Remedy (or "Three Pillar") Framework on Business and Human Rights and the Guiding Principles on Business and Human Rights represent a significant step in this direction. These UN-level efforts are complemented by the OECD Guidelines for Multinational Enterprises and ILO Tripartite Declaration of Principles concerning Multinational Enterprises and Social Policy. However, these international developments are mostly attributable to a set of 'soft' law instruments adopted by aforementioned international organizations, while so far no 'hard' law has been adopted in the given field at the international level. Nevertheless, it is noteworthy that some efforts were invested in that regard. The adoption of Resolution A/HRC/26/L.22/ Rev.1 for the "Elaboration of an international legally binding instrument on transnational corporations and other business enterprises with respect to human rights" constitutes a positive step on the way to make corporations accountable for human rights' violations. The Resolution was adopted by majority at the Human Rights Council's 26th Session on 26th June 2014 in spite of the opposition coming mainly from the USA and the EU. ${ }^{2}$

At the same time, the international developments related to corporate accountability were further endorsed by national regulatory and judicial efforts, most notably in the adoption of the Alien Tort Claims Act in the United States (US). ${ }^{3}$ This act allows, inter alia, non-US citizens to file a case in US federal court for torts committed by corporations in violation of international law. However, recent tendencies in the US jurisprudence have significantly limited one of the main avenues for victims of corporate human rights violations leading to multiple suits against corporate actors for human rights abuses committed abroad being thrown out of US courts. More concretely, the US Supreme Court held in Kiobel v. Royal Dutch Petroleum in 2011 that federal courts do not have jurisdiction over those cases unless the given claims "touch and concern" the United States with "sufficient force." 4

\footnotetext{
${ }^{1}$ S. Khoury, D. Whyte, New Mechanisms of Accountability for Corporate Violations of Human Rights, www.livrepository.liverpool.ac.uk/3001783/1/New\%20mechanisms $\% 20$ of\%20accountability $\% 20$ for $\% 20$ corporate\%20violations\%20of\%20human\%20rights.pdf, last visited December 1, 2018.

${ }^{2}$ Ibid., 2.

${ }^{3}$ S. Khoury, "Transnational Corporations and the European Court of Human Rights: Reflections on the Indirect and Direct Approaches to Accountability”, Sortuz, Oñati Journal of Emergent Socio-Legal Studies, Volume 4, 1/2010, 100.

${ }^{4}$ M. Fasciglione. "Corporate Liability, Extraterritorial Jurisdiction and the Future of the Alien Tort Claims Act: Some Remarks After Kobel”, Diritti Umani e Diritto Internazionale, Società editrice il Mulino, Volume 7, 2/2013, 412-413.
} 
The severe narrowing of this national avenue of redress for victims of corporate human rights violations shed the light to the importance of other effective avenues for victims of corporate human rights violations, which are available at the regional level, such as the European Court of Human Rights (ECtHR) and the Inter-American Court of Human Rights. Both supranational courts are engaged in scrutinizing potential violations of human rights by companies, even though they are not entitled to hold them accountable.

The case law of the Inter-American Court of Human Rights will remain out of the focus of this paper as it is considerably less extensive than that of the ECtHR, due to fact that private entities do not have standing before the former court. Instead, this paper will firstly examine whether it is more feasible for the ECtHR, at this stage of development of European human rights system, to apply the concept of indirect or direct corporate accountability. The paper will further critically assess to what extent the ECtHR so far, applying the indirect approach to corporate accountability, has scrutinized the possible violations of human rights allegedly committed by corporate entities. The paper is expected to conclude that the case-law of the ECtHR in the field of accountability of corporate entities for human rights violations has to be further developed as to ensure that afforded protection for victims of corporate human rights violations goes hand in hand with the achieved level of protection of the fundamental rights of corporate entities before the ECHR.

\section{Direct v. Indirect Approach to Corporate Accountability}

The scholars are divided on the question of the best way for ECtHR to deal with the human rights violations committed by corporate entities. Some authors claim that the introduction of direct accountability of corporate entities before the ECtHR constitutes the most feasible way for the ECtHR to deal with the human rights violations committed by corporations, the so called direct approach. ${ }^{5}$

The direct approach to corporate accountability is primarily criticized as it would imply the elevation of corporations to the status of states in international public law. It is argued that, at this stage of development of the European human rights system, it is not realistic to expect that there is a political will to amend the ECHR as to introduce

${ }^{5}$ E.A. Alkema, "The Third-Party Applicability or 'Drittwirkung' of the European Convention on Human Rights", In: Protecting Human Rights: the European Dimensions/ Protection des dro its de l'Homme: la dimension européenne: Studies in honour of/Mélange en l'honn eur de Gérard J. Wiarda (eds. F. Matscher, H. Petzold), Carl Heymanns Verlag KG, Berlin 1990², 33-57. 
an additional formal procedure that will allow a radical change such as the lodging of a complaint against a private person. ${ }^{6}$ Furthermore, it is stressed that application of the concept of direct liability of corporate entities seems to be a profoundly unfeasible option in the near future, as it would be more realistic to presume that the international community can watch the States than an inestimable number of private entities. On the other hand, the states are those that are the most suitable to insist that its nationals comply with international law. ${ }^{7}$

On the other hand, the stance taken by the other group of authors seems better grounded. They argue for the application of indirect approach to corporate accountability, which implies maintaining the state-centered approach of the ECHR system. Supporters of indirect approach claim that even though, for the time being, private actors do not have direct obligations under the ECHR, they may still violate the ECHR as long as they infringe the protected rights. ${ }^{8}$

In justifying their approach, they remind that the ECtHR, through its jurisprudence, established that certain provisions of the ECHR may be interpreted as to impose positive obligations "not only on Member States, but also, indirectly, on private persons", thus including corporate entities. ${ }^{9}$ In that context, particularly relevant are Article 1 and Article 17 of the ECHR, which provide textual hook upon which to hang the concept of indirect liability of corporate entities. ${ }^{10}$ Firstly, Article 1 explicitly secures to everyone within Contracting Parties' jurisdiction the rights set forth in the ECHR, without providing additional requirements such as that those rights, in order to be secured, must be violated directly by the state authorities. By doing so, Article 1 leaves room for the development of the concept of indirect corporate accountability. Article 17 is of key importance for the justification of the indirect approach to corporate accountability as it explicitly prohibits any act of abuse of the ECHR rights to be committed either by state or private individuals.

However, the concept of indirect accountability is also criticized among scholars, as it does not create obligations for private entities, which can be enforced through respective supervisory organs in an

\footnotetext{
${ }^{6}$ C.M. Vasquez, "Direct vs. Indirect Obligations of Corporations under International Law", Columbia Journal of Transnational Law, Volume 43, 2005, 936 etc.

${ }^{7}$ S. Khoury, 86.

${ }^{8}$ See for instance L. Garlicki, "Relations between Private Actors and the ECHR", in: The Constitution in Private Relations (eds. A. Sajó, and R. Uitz), Eleven International Publishing, Utrecht 2005, 132 etc.

${ }^{9}$ Ibid.

${ }^{10}$ D. Spielmann, "Companies in the Strasbourg Courtroom”, Cambridge Journal of International and Comparative Law, Vol. 5, 3/2016, 411.
} 
international forum. ${ }^{11}$ This constitutes a major limitation of the indirect approach to the human rights law endorsed by the ECtHR. In the absence of an international supervisory mechanism to enforce the obligations of private entities, it is left within a State's "margin of appreciation" to decide about how to ensure respect of human rights obligations between private entities. In other words, corporations can bypass any accountability by avoiding litigation before national courts. ${ }^{12}$

Notwithstanding the existing limitations of the indirect approach to provide fully effective protection to victims, at this stage of development of international human rights law, it seems needed to examine the current application of this concept and to propose its further improvements. The application of indirect approach is legitimate as only through scrutinizing the potential human rights violations allegedly committed by the corporate entities, a balance may be created with the high level of protection of corporate entities as potential victims of human rights violations, which has been so far provided by the ECtHR. Namely, the legitimacy of considering corporations as potential victims of human rights violations has never been truely questioned by the ECtHR. Its extensive case-law concerning the protection of property, respect for home and privacy and freedom of expression shows the successfulness of claims which were brought by the companies. ${ }^{13}$ In addition, by placing a particular emphasis on the concept of indirect corporate accountability, the ECtHR may contribute to decreasing the rate of corporate involvement in human rights violations.

\section{The Extent to which the ECtHR Scrutinizes the Potential Violations of Human Rights Attributable to Corporate Entities}

In order to determine the extent of the ECtHR reach to corporations it is firstly important to identify the "tools" the ECtHR applies in that group of cases as to enable the application of the concept of indirect accountability of corporate entities. Thus far, the ECtHR approached the indirect corporate accountability and has called for regulation of corporate activities at the national level by means of applying the doctrine of horizontal effect of the ECtHR rights (Drittwirkung) and the doctrine of positive obligations of the states. Besides those "tools", the ECtHR

${ }^{11}$ See for instance E.A. Alekma, 41-43.

${ }^{12}$ S. Khoury, 88.

${ }^{13}$ See A. Višekruna, "Protection of Rights of Companies before the European Court of Human Rights", in: Procedural Aspects of EU Law (D. Duić, T. Petrašević), Faculty of Law Josip Juraj Strossmayer University of Osijek 2017, 111-126. 
also occasionally relies on the following principles of interpretation when applies the concept of indirect corporate accountability: the principle of living instrument and the principle according to which protection of the ECHR's rights must be practical, concrete and effective, and not illusory or theoretical. ${ }^{14}$

When it comes to the positive obligations doctrine, it was inaugurated by the ECtHR in 1968 in the Belgian Linguistics Case concerning the right to education guaranteed in Article 2 of the Protocol 1 to the ECHR. Ten years later in the case Marckx v. Belgium, the ECtHR clearly distinguished, for the first time, among its positive and negative obligations stating that Article 8, which guarantees the right to respect for private and family life "does not merely compel the State to abstain from such interference: in addition to this primarily negative undertaking, there may be positive obligations inherent in an effective 'respect' for family life". Through its case law, the ECtHR gradually extended the reach of the doctrine of positive obligations to a broad spectrum of rights guaranteed by the ECHR, including, inter alia, Articles 2, 3, 8, 10 and 11 .

On the other hand, the doctrine of horizontal effect (Drittwirkung) derives from the German theory of the application of fundamental rights values between private parties. Instead of literally adopting Drittwirkung, as such, the ECtHR has established in its case law that ECHR's rights, including those guaranteed by Articles 3, 8-11 and 13, may apply in the private sphere, although indirectly. Drittwirkung is considered to be a very complex concept in international human rights law. It is generally acknowledged that the ECtHR applies this doctrine to a lesser extent than the doctrine of positive obligations. ${ }^{15}$

The ECtHR, in its case law, establishes a link between the doctrine of horizontal effect and positive obligations by reiterating that 'positive obligations may involve adoption of measures even in the sphere of the relations of individual between themselves'. Their connection is further identified by the scholars who hold that positive obligations and the horizontal effect are 'two sides of the same coin', or 'two things which go hand in hand' given that the State guarantees the rights in the ECHR and must do everything to ensure their protection, which does not necessarily amount to abstaining from interference, but in certain cases requires adoption of measures in the sphere of the mutual relations between individuals. ${ }^{16}$

\footnotetext{
${ }^{14}$ D. Spielmann, 412.

${ }^{15}$ S. Khoury, 86-88.

${ }^{16}$ Ibid.
} 
Although those 'tools' on which the ECtHR relies when applying the concept of indirect corporate accountability can be easily identified in the jurisprudence of the ECtHR, it is quite difficult, based on the available case law, to determine their precise scope particularly when it comes to the extent to which they allow the ECtHR to scrutinize possible violations of human rights committed by corporate entities. The ECtHR was even expressly reluctant to elaborate upon some general theory of applicability of the doctrine of horizontal effects in the private sphere in Vgt Verein gegen Tierfabriken v. Switzerland. Namely, in that case the ECtHR declared that "[it] does not consider it desirable, let alone necessary, to elaborate a general theory concerning the extent to which the Convention guarantees should be extended to relations between individuals inter se".

Therefore, in order to provide grounds for further development and conceptualization of the specific theory on the extent to which the ECHR's guarantees are applicable to victims of human rights violations committed by the corporate entities, the relevant case law of the ECtHR pertaining to the indirect corporate accountability needs to be examined in more detail.

Many cases before the ECtHR pertain to the acts or omissions which were allegedly committed by corporate entities. Those cases have been initiated under different provisions of the Convention and the Protocols, including (inter alia) Article 2, Article 3, Article 4, Article 8, Article 10 and Article 14 of the ECtHR. To put it differently, the existing body of case law relevant for the concept of indirect corporate accountability predominantly extends to the following issues: environment, ${ }^{17}$ surveillance at workplace, ${ }^{18}$ personal data protection, ${ }^{19}$ trafficking in human beings, ${ }^{20}$

\footnotetext{
${ }^{17}$ The ECtHR's case of Özel and Others v. Turkey (App. Nos. 14350/05, 15245/05 and 16051/05, Judgement of 17 November 2015) is an important case pertaining to the death which resulted from natural disaster. In this case the ECtHR held that there had been a violation of Article. See also Guerra v. Italy, App. No. 116/1996/735/932, Judgement of 19 February 1998, Lopez Ostra v. Spain, App. No. 16798/90, Judgement of 9 December 1994, Budayeva v Russia, App. Nos. 15339/02, 21166/02, 20058/02, 11673/02 and 15343/02, Judgement of 20 March 2008 and Kolyadenko and Others v. Russia, App. Nos. 17423/05, 20534/05, 20678/05, 23263/05, 24283/05 and 35673/05, Judgement of 28 February 2012.

${ }^{18}$ For instance, see the decision on admissibility in the case Köpke v. Germany, App. No. 420/07, Decision of 5 October 2010 and the case López Ribalda and Others v. Spain, App. Nos. 1874/13 and 8567/13, Judgement of 09 January 2018, Referral to the Grand Chamber, 28 May 2018.

${ }^{19}$ See for instance, Satakunnan Markkinapörssi Oy and Satamedia Oy v. Finland (App. No. 931/13, Judgement of 27 June 2017, Grand Chamber), where the ECtHR found that there was no violation of Article 10.

${ }^{20}$ For instance, in the case Rantsev v. Cypres and Russia, (App. No. 25965/04, Judgement of 7 January 2010) the ECtHR found the violation of Articles 2 and 4. This constitutes a landmark judgement whose subject-matter was human trafficking. More concretely, it deals with the sexual exploration which was committed by commercial operators.
} 
safeguarding the health and safety of workers. ${ }^{21}$

Although the ECtHR case law on the issue of indirect corporate accountability prima facie seems very extensive, it does not mean that it contains a lot of judgements finding human rights violations that are committed by corporate entities. It is important to keep in mind that most of the claims brought to the ECtHR did not result in rulings determining violations of the ECtHR. Moreover, in order to properly select and understand the relevant case law it firstly should be distinguished between indirect accountability of private and public corporate entities. The notion of corporate accountability, applied by both scholars and international lawyers, in principle, covers both categories of corporate entities.

However, this section is mainly focused to the cases where the accountability is attributable to private corporations; as such cases turn to be more problematic in practice. While the acts or omissions of the public corporate entities are automatically attributable to the respective state as a respondent, the same apparently does not apply to acts or omissions committed by private corporate entities. As it was elaborated, in those group of cases the link between a private corporate and a state entity shall be established by the ECtHR, through invoking the doctrine of horizontal effect or positive obligations doctrine. However, the existing body of ECtHR's case law shows that in certain instances, the ECtHR missed the opportunity to establish the given link, which further resulted in the rulings finding no violations of the ECtHR without providing any justification in that regard.

Apparently, the main weakness of the indirect approach to corporate accountability is evident in the lack of the conceptualization of the indirect corporate accountability, or more concretely, in the ECtHR failure to specify the human rights obligations of companies and the extent to which it can scrutinize violations allegedly committed by them. In that context, Verdonck rightly observed in his comment on Özel v. Turkey that given that 'the international legal framework burdens States with a tremendous responsibility to enforce corporate accountability, human rights bodies could at least create a level playing field regarding the concrete duties of corporate entities'..$^{2}$

Therefore, in most of cases where the ECtHR found violation of the certain provision of the ECHR, such as for instance the case of $\ddot{O z e l}$

${ }^{21}$ Vilnes and Others v. Norway, App. Nos. 52806/09 and 22703/10, Judgement of 5 December 2013.

${ }^{22}$ L. Verdonck, "How the European Court of Human Rights evaded the Business and Human Rights Debate in Özel v. Turkey", The Turkish Commercial Law Review, Vol. 2, 2016, 115. 
v. Turkey, it failed to explicitly mention the responsibility of the involved corporations. Instead, the ECtHR judged such cases purely in light of the state's shortcomings. In that context, Verdonck further indicates that the ECtHR 'should have discussed the interplay between different liability regimes - state versus private actor liability, criminal versus civil liability and corporate versus individual liability'. ${ }^{23}$ The given remarks are mostly applicable to the entire body of ECtHR's case law, given that the ruling in Özel v. Turkey is in line with the ECtHR's established case law on corporate accountability.

The lack of the systematic ECtHR approach towards corporate accountability is also evident at terminology level. The ECtHR so far has not coined uniformed terminology regarding this matter. It did not use the term of "corporate accountability" in any single ruling. Instead of that, it occasionally recourses to different terms such as "accountability", "companies", "business interests", "commercial interest" when it tries to explain its approach to corporate accountability.

Finally, it is a bit disappointing that the ECHR in times of significant development of international soft and hard law instruments on corporate accountability did not seize the opportunity to invoke and elaborate on some of international soft law instruments while scrutinizing the possible violations of human rights committed by corporate entities. The fact that the ECtHR did not quote any of the international acts on corporate accountability contradicts to approach it follows when adjudicating on some other issues, such as for instance prohibition of torture guaranteed under Article 3. On the other hand, the ECtHR invokes some international conventions pertaining to trafficking in its case law on corporate accountability, for instance in the cases Siliadin v. France and Rantsev $v$. Cyprus and Russia ${ }^{24}$ without giving any mention to the applicable set of instruments on corporate accountability.

\section{Conclusion}

Currently, no international human rights judicial body, except the International Criminal Court, has jurisdiction to hold private actors accountable. However, the prosecution of corporations was expressly excluded from the International Criminal Court. On the other hand,

${ }^{23} \mathrm{Ibid}$.

${ }^{24}$ Siliadin v. France, App. No. 73316/01, Judgement of 26 October 2005; Rantsev v. Cyprus and Russia, App. No. 25965/04, Judgement of 7 January 2010. 
there is an ever increasing number of international 'soft' law instruments that were adopted by various organizations such as the UN, OECD, EU and ILO. In order to bridge that gap as well as to strengthen and further improve the implementation of the concept of corporate accountability, the ECtHR should take more active and clear approach by specifying clear conditions and formulating a test on how to best scrutinize possible violations of human rights committed by the corporate entities and consequently, their accountability.

Instead of that, the approach the ECtHR taken so far has been neither consistent nor comprehensive. In most of cases where the ECtHR found violation of certain provision of the ECHR, such as for instance the case of Özel v. Turkey, it declined to explicitly mention the responsibility of the involved corporations. Instead, the ECtHR judged such cases purely in the light of the State's shortcomings. By specifying the conditions under which it scrutinizes possible violations of human rights committed by corporate entities, the ECtHR would surely 'eliminate discrepancies under national laws and create a level playing field by identifying and developing minimum requirements'.${ }^{25}$ Furthermore, a more consistent and comprehensive approach on the scrutinizing the corporate accountability is also needed as to strike a fair balance with the high level of protection of corporate entities as potential victims of human rights violations, which has been so far awarded by the ECtHR.

Finally, such a proactive role of the ECtHR that we suggest is in line with its established dynamic approach, which implies that the ECtHR extends and applies the ECHR 'in light of political and social developments and changes of conditions of life, beyond the original conceptions of the period when the Convention was drafter or entered into force' ${ }^{26}$ In favor of the application of such dynamic approach is also the International Law Commission in its report on fragmentation.

\section{References}

Alkema E.A., "The Third-Party Applicability or 'Drittwirkung' of the European Convention on Human Rights", In: Protecting Human Rights: the European Dimensions/Protection des dro its de l'Homme: la dimension européenne: Studies in honour of/ Mélange en l'honn eur de Gérard J. Wiarda (eds. F. Matscher, H. Petzold),

\footnotetext{
${ }^{25}$ L. Verdonck, 117.

${ }^{26}$ S. Khoury, 82.
} 
Carl Heymanns Verlag KG, Berlin 1990², 33-57.

Fasciglione, M., "Corporate Liability, Extraterritorial Jurisdiction and the Future of the Alien Tort Claims Act: Some Remarks After Kobel",

Diritti Umani e Diritto Internazionale, Società editrice il Mulino, Vol. 7, 2/2013, 401-435.

Garlicki, L., "Relations between Private Actors and the ECHR", in: The Constitution in Private Relations (eds. A. Sajó, and R. Uitz), Eleven International Publishing, Utrecht 2005, 129-144.

Khoury, S., "Transnational Corporations and the European Court of Human Rights: Reflections on the Indirect and Direct Approaches to Accountability", Sortuz, Oñati Journal of Emergent Socio-Legal Studies, Volume 4, 1/2010, 68-110.

Spielmann, D., "Companies in the Strasbourg Courtroom", Cambridge Journal of International and Comparative Law, Vol. 5, 3/2016, 404-417.

Vasquez, C.M., "Direct vs. Indirect Obligations of Corporations under International Law", Columbia Journal of Transnational Law, Volume 43, 2005, 927-959.

Verdonck, L., "How the European Court of Human Rights evaded the Business and Human Rights Debate in Özel v. Turkey", The Turkish Commercial Law Review, Vol. 2, 2016, 111-118.

Višekruna, A., "Protection of Rights of Companies before the European Court of Human Rights“, in: Procedural Aspects of EU Law (D. Duić, T. Petrašević), Faculty of Law Josip Juraj Strossmayer University of Osijek 2017, 111-126.

\section{Legal sources}

Özel and Others v. Turkey, App. Nos. 14350/05, 15245/05 and 16051/05, Judgement of 17 November 2015

Guerra v. Italy, App. No. 116/1996/735/932, Judgement of 19 February 1998 Lopez Ostra v. Spain, App. No. 16798/90, Judgement of 9 December 1994 Budayeva v. Russia, App. Nos. 15339/02, 21166/02, 20058/02, 11673/02 and 15343/02, Judgement of 20 March 2008

Kolyadenko and Others v. Russia, App. Nos. 17423/05, 20534/05, 20678/05, 23263/05, 24283/05 and 35673/05, Judgement of 28 February 2012

Köpke v. Germany, App. No. 420/07, Decision of 5 October 2010 López Ribalda and Others v. Spain, App. No. 1874/13 and 8567/13, Judgement of 9 January 2018, Referral to the Grand Chamber, 28 May 2018 Satakunnan Markkinapörssi Oy and Satamedia Oy v. Finland, App. No. 
931/13, Judgement of 27 June 2017, Grand Chamber

Rantsev v. Cypres and Russia, App. No. 25965/04, Judgement of 7 January 2010 Siliadin v. France, App. No. 73316/01, Judgement of 26 October 2005 Marckx v. Belgium, App. No. 6833/74, Judgement of 13 June 1979

Kiobel v. Royal Dutch Petroleum Co., Decision of the United States Supreme Court, 569 US 108 (2013)

Vgt Verein gegen Tierfabriken v. Switzerland, App. No. 24699/94, Judgement of 28 June 2001

Vilnes and Others v. Norway, App. Nos. 52806/09 and 22703/10, Judgement of 5 December 2013

Resolution A/HRC/26/L.22/Rev.1 for the "Elaboration of an international legally binding instrument on transnational corporations and other business enterprises with respect to human rights"

\section{Website references}

Khoury, S., Whyte, D., New Mechanisms of Accountability for Corporate Violations of Human Rights, www.livrepository.liverpool. ac.uk/3001783/1/New\%20mechanisms\%20of\%20accountability\%20for\%20corporate\%20violations\%20of\%20human\%20 rights.pdf, last visited 1 December 2018.

\section{Dr Vesna Ćorić}

Naučni saradnik, Institut za uporedno pravo

Dr Ana Knežević Bojović

Naučni saradnik, Institut za uporedno pravo

\section{INDIREKTNI PRISTUP ODGOVORNOSTI PRIVREDNIH SUBJEKATA U SVETLU PRAKSE EVROPSKOG SUDA ZA LJUDSKA PRAVA}

\section{Rezime}

Sudska praksa Evropskog suda za ljudska prava (ESLJP) u vezi sa zaštitom ljudskih prava pravnih lica, uključujući i privredne subjekte, je dobro razvijena i analizirana u pravnoj literaturi. Međunarodno pravo 
ljudskih prava se razvija u pravcu uspostavljanja pravila i prakse utvrđivanja odgovornosti za povrede ljudskih prava ne samo u odnosu na države, već i odgovornosti drugih pravnih lica, naročito privrednih subjekata. Autorke u ovom radu analiziraju način na koji je ESLJP u svojoj sudskoj praksi konceptualizovao odgovornost privrednih subjekata za povredu ljudskih prava. U radu autorke ukazuju na to da je u svojoj dosadašnjoj praksi ESLJP uglavnom pristupao odgovornosti privrednih subjekata i ukazivao na potrebu regulisanja aktivnosti poslovnih subjekata na nacionalnom nivou kroz primenu doktrine horizontalnog dejstva prava zajemčenih Evropskom konvencijom o ljudskim pravima (Drittwirkung) i doktrine pozitivnih obaveza država. Autorke potom iznose stav da je ESLJP na taj način u svojoj praksi propustio da u punoj meri uzme u obzir opšte tendencije u razvoju društvenih odnosa i politika, te da bi zapravo trebalo da preuzme proaktivnu ulogu u konceptualizaciji svog pristupa i postupanja u slučajevima povrede ljudskih prava od strane privrednih subjekata.

Ključne reči: odgovornost privrednih subjekata, ESLJP, povreda ljudskih prava, horizontalno dejstvo, pozitivne obaveze država. 